\title{
The Relationship between Leader Member Exchange and Teacher Job Satisfaction
}

\author{
Charnetta Robinson, Ed.D \\ St. Tammany Parish Public School System \\ Harrison Curriculum Center \\ 706 West $28^{\text {th }}$ Ave. \\ Covington, LA 70433, USA \\ Roslin Growe, Ed.D \\ University of Louisiana at Lafayette \\ P. O. Box 43091 \\ Lafayette, LA 70504, USA
}

\begin{abstract}
The evolving educational landscape rendered by the introduction of accountability measures such as Compass, Common Core, and PARCC has created significant challenges for K-12 educators in Louisiana and has contributed significantly to a revolving door among many educators in and out of the profession. Consequently, the recurring problem of teacher attrition continues to be an issue for educators in America and the relationship that teachers develop with their leaders becomes increasingly important. A quantitative study was conducted to explore a possible relationship between leader member exchange and teacher job satisfaction. Incorporating the theoretical lens of the Leader Member Exchange Theory, data was collected using the LMX-7, Job Satisfaction Survey, and a demographic questionnaire developed for teachers at three schools in a single school district in Louisiana.
\end{abstract}

Key words: Teacher Job Satisfaction, School Leadership, LMX Leadership Theory, Leader Style

\section{Contextual Background}

In Louisiana, the infusion of the Common Core State Standard Initiative and the Compass Evaluation System increased pressure on local educators to perform. The mechanisms for accountability continue to become increasingly more stringent, and some teachers do not feel adequately prepared. The teacher preparation programs, alternative certification programs, and districts' new teacher induction programs continue to be criticized and do not appear to be providing a sufficient foundation and training to support teachers remaining in the classroom (Louisiana Department of Education, 2014). Beginning teachers continue to express challenges with managing classroom procedures, dealing with difficult parents, differentiating instruction, handling difficult student behaviors, and effectively accessing student learning (Gourneau, 2014).

A recent study discovered similar findings. Teachers in the states of Texas, Alabama, South Carolina, and Maryland were surveyed regarding their feelings toward the implementation of Common Core. Although all of the teachers felt comfortable with the ultimate implementation of the standards, nearly $55 \%$ of the teachers indicated that they did not receive adequate training and only $24 \%$ of the teachers indicated that their students were prepared to master the standards (Burks, et al., 2015).

There are multiple reasons offered for teachers' exodus that dates back to the 1990's. The parameters that are presently enforced by the No Child Left Behind mandate for teachers not highly qualified continue to lower the morale among teachers, resulting in a lack of desirability for the profession. In addition, teacher salaries are not competitive when compared with other professional careers requiring a 4-year degree. There are also minimal incentives offered for the pursuit of advanced degree attainment. Finally, inadequate classroom resources are among the chief reasons offered for teacher frustration. The rise of teacher burnout, and subsequent sub-par work performance, and declining job satisfaction is becoming an unfortunate reality (Hoigaard, Giske, \& Sundsli, 2012; Jones \& Youngs, 2012; Kopkowski, 2008).

\section{Problem Statement}

The role of educational leaders appears to be of paramount importance in this ever-changing learning environment (Graen \& Uhl-Bien, 1995). The fluctuating landscape in public education has led to increased teacher attrition. Teachers' report that factors including working conditions, leadership, pay and benefits, and overall work stresses challenge a favorable working environment. 
External rewards and commendations stimulate motivation and consequently job satisfaction (Thornton, Peltier, \& Medina, 2007). This study explored the relationship between leader member exchange and teacher job satisfaction.

\section{Significance of the Study}

There is a dearth of research on the leader and follower relationship. The significance of this study is that it will add a new context to the body of research on this relationship while simultaneously evaluating the relationship of leader member exchange on job satisfaction. Most of the research related to job satisfaction and leadership style has been conducted in health care organizations and industry. Previous inquiries have explored this type of research from the viewpoint of one-sided leadership perspectives. This traditional approach tends to highlight characteristics of the leader or follower and limits the focus of the leadership relationship. Leader Member Exchange Theory offers an opportunity for supervisors to consider LMX quality with subordinates (Graen \& Uhl-Bien, 1995; Loi, Chan, \& Lam, 2014).

The study will shed light on the pivotal role that leadership plays on the reactions and responses of teachers to changes in the public educational system. The issue will be explored within a novel context: a public-school system located in the southeastern region of the United States. Relevance of the investigation lies within the utilization of the most recently developed and revised instrument measuring leader member exchange. Meta-analysis showed that the LMX-7 measure has the soundest psychometric properties of all instruments measuring leader member exchange and that the LMX-7 is congruent with numerous empirical relationships associated with transformational leadership (Gerstner \& Day, 1997).

\section{Research Questions}

This following questions will be addressed in this study:

1. What are the demographic characteristics of public elementary school teachers in southeast Louisiana?

2. What are the perceived levels of the leader member exchange among public elementary school teachers in southeast Louisiana?

3. What are the perceived levels of job satisfaction among public elementary school teachers in southeast Louisiana?

4. To what extent is there a relationship between leader member exchange and teacher job satisfaction among public elementary school teachers in southeast Louisiana?

\section{Education-K-12}

Job satisfaction has been studied in higher education, and the topic has been explored in K-12 populations as well. As an illustration, a study was conducted among kindergarten teachers in Jordan. The primary purpose of this study was to determine the level of job satisfaction among the teachers in relation to work-related dimensions (classroom physical environment, relationships with staff, working conditions, salary, children's behavior, and parental participation) and socio-demographic variables (teacher's age, marital status, level of education. Teachers were highly satisfied with classroom physical environment and their relationships within the school. Teachers reported average satisfaction with working conditions, children's social behavior and parent participation. Younger kindergarten teachers appeared more satisfied with their jobs. Kindergarten teachers with bachelor's degrees were more satisfied with their jobs, whereas as teachers with advanced degrees were looking to secure advance positions (Abu Taleb, 2013).

Similarly, job satisfaction was explored among elementary school teachers in China with efforts to gain greater insights into their attitudes and work behavior. The researchers compiled job satisfaction questionnaires by means of surveys and scientific statistics, explored, and created models of the structure of job satisfaction, and identified the extrinsic and intrinsic factors affecting teacher job satisfaction. The intrinsic factors that were identified as most impactful to job satisfaction were the nature of the job itself, relationship with colleagues, social acknowledgement, and professional input. The extrinsic factors that were found to impact job satisfaction most among teachers were administration, working conditions, achievement, work stress, welfare, student quality, salaries, and promotion. This information can prove insightful for effective administration (Song, 2007).

Job satisfaction has also been examined in relationship to other variables. The relationship between job satisfaction and burnout levels, hopelessness, and procrastination was explored among primary and secondary school teachers (Kumcagiz, Ersanli, \& Alakus, 2014). A statistically significant negative relationship was discovered between job satisfaction and burnout, hopelessness, and procrastination. As teachers became increasingly more burned out, felt greater hopelessness, and began to procrastinate more, their feelings of job satisfaction went down. High job satisfaction of teachers will enable them to better focus on their work and be more efficient at work. 


\section{LMX and Job Satisfaction}

Graen and Novak (1982) looked at how leader member exchange and job design impacted productivity and satisfaction among one hundred and six employees of a large public service organization using an experimental design. Four treatment conditions were compared including leader member exchange, job design, a combination, and a placebo control on satisfaction and productivity. The results indicated that only the LMX condition resulted in significant before-after-gains. LMX leadership training had strong effects on quantity of production and not at the expense of quality of production. The findings indicated that LMX had no significant impact on job satisfaction.

Similarly, Janssen and Yperen (2004) proposed that Leader Member Exchange was an interpersonal mechanism that mediated the relationships between employees' goal orientations and the outcomes of job performance and job satisfaction. Using a cross sectional design, they surveyed over two hundred fifty employees of a Dutch energy supply company working in various capacities. The findings supported a positive relationship between LMX and job satisfaction and performance. In addition, mastery orientation was positively related to the role job performance, innovative job performance, and job satisfaction. The quality of LMX mediated those relationships (Janssen \& Yperen, 2004).

\section{Conceptual/Theoretical Framework}

The degree of employee satisfaction is related to the exchange or dyadic relationship between the leader and follower which is the core of the Leader Member Exchange Theory (Janssen \& Yperen, 2004). The dyadic relationship refers chiefly to the quality of exchange between the leader and subordinate. High quality exchange relationships are characterized chiefly by more autonomy and responsibility being offered to the subordinate. High quality exchanges are also referred to as leadership exchanges. In low quality exchange relationships, the supervisor relies on formal power of the position to influence the subordinate. Low quality exchanges are also referred to as supervisory exchanges.

The theoretical framework for this research study is rooted in the Leader Member Exchange Theory (LMX) (Graen \& Uhl-Bien, 1995). The key premise of LMX theory is the exchange relationship between a leader and a member and the subsequent influence on many organizational outcomes such as job satisfaction (Liden, Sandy, \& Stillwell, 1993). When leaders operate through the lens of LMX, they differentiate between subordinates in the work group rather than presenting an average leadership style to all.

The three constructs within the LMX theoretical framework are trust, respect, and mutual obligation. LMX and trust have been viewed as relational. The way in which leaders and subordinates perceive each other's level of trust impacts their exchange. Leadership and management practices will contribute greatly to increasing trust and trust can still be fragile among leaders and members with high quality relationships (Dirks \& Ferrin, 2002; Scandura \& Pellegrini, 2010). Regarding respect, the impact on job satisfaction appears greater in ethnic minorities, women, and those without college education. Pay, trust in management, level of empowerment also impacted workplace satisfaction and organizational commitment (Laschinger \& Finegan, 2005).

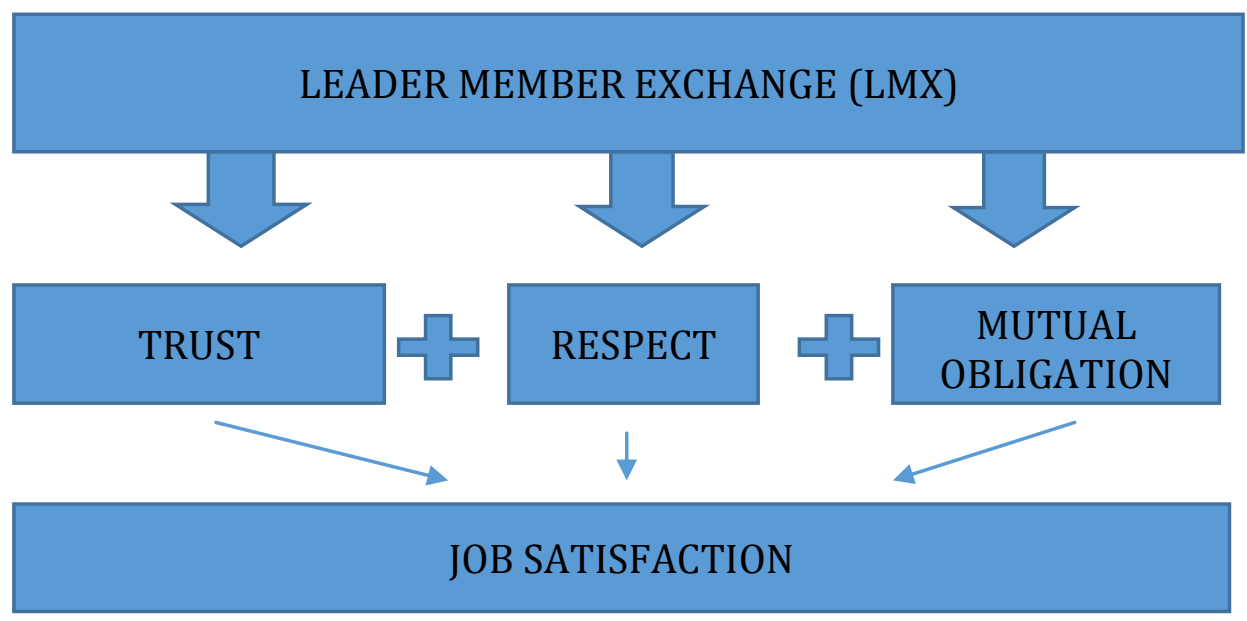

\section{Methodology}

The current study has several goals. To begin, the interconnectedness of poor leadership, unfavorable conditions, and work stress is linked to job dissatisfaction and in many school's teacher exodus. 
Next, the Leader Member Exchange Theory was introduced and detailed as a more holistic response to describing leadership because it does not limit the focus to the leader or the follower but instead highlights the leadership relationship (Chen, 2007; Graen \& Uhl-Bien, 1995; Loi, Chan, \& Lam, 2014; Thornton, Peltier, \& Medina, 2007). In short, establishing an optimal leader and subordinate relationship could potentially circumvent mass teacher exodus and aid in the development of effective teacher retention strategies.

Therefore, the purpose of this study was to explore a possible relationship between leader member exchange and teacher job satisfaction.

\section{Research Design}

The relationship between leader member exchange and job satisfaction were explored. One of the essential functions of quantitative research is to examine relationships between variables. Moreover, the feelings, values, and perceptions that underlie and influence behavior were considered.

There are two modes of inquiry that comprise quantitative research (Gay, Mills, \& Airasian, 2009; Huck, 2012; McMillan \& Schumacher, 2001). The two modes of inquiry are experimental and non-experimental. The nonexperimental modes of inquiry examine relationships between variables without direct manipulation of conditions that are experienced. In the current study, the non-experimental mode of inquiry referred to as correlational research will be used. Correlational research measures a degree of association between the two variables of interest. A positive correlation means high values of one variable are associated with high values of a second variable. A negative association means high values of one variable are associated with low values of a second variable. In the current study, the two variables that will be correlated are leader member exchange and job satisfaction (McMillan \& Schumacher, 2001).

For each school, the principals' years of experience as an administrator will vary. All of the schools selected were high poverty schools. The high poverty classification was determined based on the Title I classification given to schools in the district by the federal government annually. This classification is determined based on the percentage of enrolled students at the school receiving free or reduced lunch during the current school year. According to the district's federal programs' office, the school must meet national standards with at least $40 \%$ of the students being enrolled in the free and reduced lunch program for the school to be considered Title I or high poverty. Elementary School One is located in a suburban area, originally opened its doors in 1964, and serves students in grades 1-5. The current enrollment is 869, and $78.6 \%$ of students are enrolled in the free and reduced lunch program. Elementary School Two is located in a Suburban area, serves students in grades Pre-K-3, has an enrollment of 763, and 51.11\% of students are enrolled in the free and reduced lunch program. Finally, Elementary School Three is located in a rural area of the state, serves students in grades 1-5, has an enrollment of 468, and has $74.57 \%$ of students enrolled in the free and reduced lunch program (D. Cook, personal communication, October 9, 2017; Louisiana Department of Education, October 2017).

\section{Population and Sampling Plan}

The target population was public elementary school teachers. Elementary school teachers are teachers teaching any grade level between pre-kindergarten and sixth grade. There are 180 school districts in Louisiana including public school systems and charter school networks. There are 1,083 elementary schools in the state of Louisiana servicing students in kindergarten through sixth grade and 383,837 elementary school students in the state of Louisiana (Louisiana Department of Education, 2017). A more recent statistic from Ballot Pedia notes that there are 46,493 teachers currently in Louisiana however teachers are not broken down by grade level in the various data reports (BallotPedia, 2017). According to National Center for Education Statistics, there were 26,884 elementary teachers in the state of Louisiana in the Fall of 2014 (National Center for Education Statistics, 2014).

The identified sub-population is a southeastern Louisiana school district. There are 55 schools in this district, 26 of which are elementary schools that serve students in kindergarten through sixth grade. The total student enrollment is 38,$681 ; 21,670$ of which are elementary students. There are 3,226 certificated employees in this school district, 3,113 of which are certified teachers and counselors. Fifty-three percent of the certificated employees in the school district hold master's degrees (Bayou East Parish Public School System, 2016).

The three elementary schools were used for study were selected based on several criteria to ensure diversity among the schools selected. The criteria included the number of years of experience as a school administrator, the number of years as an administrator at that specific school, and the socioeconomic status of students at the school. For each school, the principals' years of experience as an administrator will vary. All of the schools selected were high poverty schools. The high poverty classification was determined based on the Title I classification given to schools in the district by the federal government annually. This classification is determined based on the percentage of enrolled students at the school receiving free or reduced lunch during the current school year. 
According to the district's federal programs' office, the school must meet national standards with at least $40 \%$ of the students being enrolled in the free and reduced lunch program for the school to be considered Title I or high poverty. Elementary School One is located in a suburban area, originally opened its doors in 1964, and serves students in grades 1-5. The current enrollment is 869 , and $78.6 \%$ of students are enrolled in the free and reduced lunch program.

Elementary School Two is located in a Suburban area, serves students in grades Pre-K-3, has an enrollment of 763, and $51.11 \%$ of students are enrolled in the free and reduced lunch program. It is worthy to note that an original school selected for inclusion in the study is located in a rural area, serves students in Pre-K-3, has an enrollment of 640, and $52.34 \%$ of students are enrolled in the free and reduced lunch program was not due to the principal's impending retirement. The principal did not grant permission for her faculty to participate in the research study. It was her opinion that the teachers may offer more situationally favorable or negative responses based on her upcoming retirement. Subsequently, Elementary School Three was selected for inclusion in the study. This school is located in a rural area, serves students in Pre-K-3, has an enrollment of 640, and 52.34\% of students are enrolled in the free and reduced lunch program (D. Cook, personal communication, March 8, 2018; Louisiana Department of Education, March 2018).

\section{Instrumentation}

The instrumentation for this study was two research instruments used in previous research and a demographic questionnaire developed by the researcher. The three instruments are discussed.

\section{Leader Member Exchange Seven-Member Version}

The Leader Member Exchange-Seven (LMX-7) is a 7- item instrument used to measure trust, respect, and mutual obligation within leader and subordinate working relationships. The LMX-7 was developed in 1995 but maintains relevance and is appropriate for use in more current research (Clemens, Milson, \& Cashwell, 2009; Cogliser, \& Schriesheim, 2000; Collins, 2010; Lawrence \& Kacmar, 2012; Scandura, \& Pellegrini, 2010; Volmer, Niessen, Spurk, Linz, \& Abele, 2011). The LMX-7 was used to assess the teacher's perception of his or her principal's contribution to the professional relationship. Participants responded based on a 5-point Likert scale ranging from strongly disagree (1) to strongly agree (5) (Graen \& Uhl-Bien, 1995).

A score is calculated on the LMX-7as a sum of responses. A score can range from 7 to 35 . In order to interpret the LMX-7, the following guidelines were used: very high $=30-35$, high $=25-29$, moderate $=20-24$, low $=15-19$, and very low $=7-14$. Scores in the upper ranges indicated stronger, higher quality leader-member exchanges which corresponded to the "in-group members." Scores in the lower ranges indicated lower quality leader-member exchanges which corresponded to the "out-group members" (Graen \& Uhl-Bien, 1995).

Table 1.1. LMX-7 Score Interpretation

\begin{tabular}{lll}
\hline \multicolumn{1}{c}{ Description } & Sum & Mean \\
Very High & $30-35$ & $4.3-5$ \\
High & $25-29$ & $3.6-4.2$ \\
Moderate & $20-24$ & $2.9-3.5$ \\
Low & $15-19$ & $2.1-2.8$ \\
$\quad$ Very Low & $7-14$ & $1-2$ \\
\hline
\end{tabular}

The LMX-7 has demonstrated predictive validity and reliability in a variety of settings. The Cronbach alphas for the single measure were consistently in the $80 \%-90 \%$ range. Internal consistency reliability was strong (coefficient $=.88$ ). The internal consistency reliabilities of member LMX-7 and leader LMX-7 were analyzed. For members, alpha was .89, and for leader's alpha was smaller .78 (Gerstner \& Day, 1997).

\section{Demographic Questionnaire}

A demographic questionnaire was developed by the researcher. The questionnaire served two purposes. It provided demographic data for Research Question5 to be used in the analysis. Secondly, the demographic questionnaire was related to participants' age, gender, years of experience as a teacher, years teaching at the current school, years having current supervisor, current grade level taught, education level, and race/ethnicity.

\section{Major Findings}

\section{Research Question 1}

What are the demographic characteristics of public elementary school teachers in southeast Louisiana? 
The demographic characteristics of public elementary school teachers in southeast Louisiana were explored in research question 1. In the current study, demographic variables that were examined using the demographic questionnaire developed by the researcher were age, gender, race, years of teaching experience, years teaching at current school, and years working with current supervisor. There were significantly more female teachers than male teachers participating in the current study. Therefore,gender was not included in the analysis due to discrepancy in the distribution.

The impact of gender on LMX could not be determined as it had been in earlier research (Milner, Katz, Fisher, \& Notrica, 2007). With regard to race, $83.8 \%$ of the teachers were White, $13.8 \%$ percent were minority (Black, Hispanic, Asian, Native American, and Alaskan Native), and 2.3\% did not respond to the race inquiry. Consistent with the literature, race did not appear to have a significant impact on leader member exchange and job satisfaction (Bozeman \& Gaughan, 2011).

The teachers participating in this study shared similar mean age range and years of experience. A significant range was observed across the schools as it related to teachers' years of teaching experience and years working with their current supervisor.

\section{Research Question 2}

What are the perceived levels of the leader member exchange among public elementary school teachers in southeast Louisiana?

The perceived levels of leader member exchange among public elementary school teachers were explored in research question 2. Across the three schools considered in the current study, the average leader member exchange levels hovered toward the middle of the leader member exchange scale which indicates a slightly positive leader member exchange level.

\section{Research Question 3}

What are the perceived levels of job satisfaction among public elementary school teachers in southeast Louisiana? The perceived levels of job satisfaction among public elementary school teachers were explored in research question 3. With regard to the individual subscales of the Job Satisfaction Scale, teachers had similar scores for supervision, coworkers, fringe benefits, and nature of work. This supports positive job satisfaction among the teachers at these schools for these particular subscales. Conversely, there is a greater range of scores among the three schools for the subscale contingent rewards (performance-based rewards). This finding could suggest that contingent rewards contributed more inconsistently to overall positive job satisfaction among teachers.

\section{Research Question 4}

To what extent is there a relationship between leader member exchange and teacher job satisfaction among public elementary school teachers in southeast Louisiana?

The perceived relationship between leader member exchange and teacher job satisfaction among public elementary school teachers in southeast Louisiana was explored in research question 4. There were negative, moderate correlations between leader member exchange and total job satisfaction. As leader member exchange levels increased, total job satisfaction decreased moderately. As leader member exchange levels decreased, total job satisfaction increased moderately. There was also a negative, moderate correlation between leader member exchange and operating conditions. Weak negative correlations were found between leader member exchange and several other job satisfaction subscales including pay, promotion, and coworkers. As leader member exchange levels increased among teachers, the subscale of operating conditions decreased. Similarly, as leader member exchange levels increased among teachers, teachers experienced decreasingly perceptions of (a) pay, (b) promotion, and (c) coworkers. Moderate to strong correlations were found between leader member exchange and several job satisfaction subscales including: (a) nature of work, (b) communication, and (c) supervision. Correlations for job satisfaction and leader member exchange were compared among the three schools to determine any significant differences. For 6 of the 10 relationships, there was not a difference between Elementary School One and Elementary School Two, but significant differences were found between Elementary School Three and each of the other schools. As discussed in Research Question 5, the leader member exchange leadership making process could attribute to this finding. The findings of the current study are consistent with the literature with regard to pay and job satisfaction being correlated. The findings supported the hypothesis of perception of fair pay and recognition of work by departmental colleagues as a strong predictor of job satisfaction among college professors (Bozeman \& Gaughan, 2011; Coomber \& Barriball, 2007; Henry, 2011).

\section{Research Question 5}

To what extent are teacher demographic characteristics and leader member exchange scores related to the level of job satisfaction among public elementary school teachers in southeast Louisiana? 
The perceived relationship between teacher demographic characteristics and leader member exchange scores related to the level of job satisfaction among public elementary school teachers in southeast Louisiana was explored in Research Question 5. When controlling for LMX, a statically non-significant $\mathrm{R}^{2}=.028$ value suggested that $2.8 \%$ of variance in job satisfaction was explained by the demographic variables which included: (a) age, (b) race, (c) years of teaching experience, (d) years at current school, and (e) years with current supervisor.

This finding is consistent with previous research that suggested that the value system of the leader and/or subordinate weighs more heavily than nationality or culture (Steiner, 1998). However, it is inconsistent with previous research that suggests that age impacts (positively or negatively) job satisfaction (Ssesanga, \& Garrett, 2005). A statistically significant $\mathrm{R}^{2}=.087$ suggested that $8.7 \%$ of the variance in job satisfaction was explained by the demographic variables (i.e. age, race, years of experience, years at current school, years with current supervisor) and/or leader member exchange.

\section{Implications for Practice}

The implications of this study could impact school principals, teachers, and district leaders. Human resource professionals who are directing recruitment and retention initiatives for the school districts may also view the findings useful in matching teachers and principals to the environment in which they are most likely to achieve success. This strategy is promising for improving both retention and student achievement (Player, Player, Youngs, Perrone, Grogan, 2017). As the outcome of the comparison correlations for job satisfaction and leader member exchange suggests, there are differences among correlations among the three schools. Elementary School One and Elementary School Three were statistically significantly different except for the relationship between LMX and pay. Elementary School One and Elementary School Two were not statistically significant different. The only relationships that were different were LMX and operating conditions and LMX and communication. Elementary School Three and Elementary School Two only had statistically significant differences with respect to the JSS subscales: pay, promotion, and operant conditions. In short, for 6 of the 10 relationships, there were no differences between Elementary School One and Elementary School Two but statistically significant differences between Elementary School Three and the other two schools. Research findings regarding the LMX levels of teachers could assist principals in determining appropriate fits for their faculty as they make future hiring decisions.

School district leaders may explore the adoption of a standardized communication protocol and/or tool to enhance communication effectiveness to increase leader member exchange. The delivery and implementation of such an initiative could potentially effect job satisfaction throughout the school district (Swarnalatha, C. \& Sureshkrishna, G., 2013).

\section{References}

Abu Taleb, T. (2013). Job satisfaction among Jordan's kindergarten teachers: Effects of workplace conditions and demographic characteristics. Early Childhood Education Journal, 41(2), 143-152.

Bozeman, B. \& Gaughan, M. (2011). Job satisfaction among university faculty: Individual, work, and institutional determinants. The Journal of Higher Education, 82(2), 154-186.

Burks B. A., Beziat, T.R., Danley, S., Davis, K., Lowery, H., \& Lucas, J. (2015). Adapting to change: Teacher perceptions of implementing the common core state standards. Education, 136(2), 253-258.

Chen, W. (2007). The structure of secondary school teacher job satisfaction and its relationship with attrition and work enthusiasm. Chinese Education \& Society, 40(5) 17-31.

Cogliser, C. \& Schriesheim, C. (2000). Exploring work unit context and leader-member exchange: A multi-level perspective. Journal of Organizational Behavior, 21, 487-511.

Collins, M.D. (2010). The effect of psychological contract fulfillment on manager turnover intentions and its role as a mediator in a casual, limited-service restaurant environment. International Journal of Hospitality Management, 29, 736-742.

Clemens, E. V., Milson, A., \& Cashwell, C.S. (2009). Using leader-member exchange theory to examine principalschool counselor relationships, school counselors' roles, job satisfaction, and turnover intentions. Professional School Counseling, 13(2), 75-85.

Coomber, B. \& Barribal, K. (2007). International Journal of Nursing Studies, 44, (2), 297-314.

Gay, L.R., Mills, E., \& Airasian, P. (2009). Educational research: Competencies for analysis and applications. $\left(9^{\text {th }}\right.$ ed.). Upper Saddle River, NJ: Pearson Education, Inc.

Gerstner, C. R., \& Day, D. V. (1997). Meta-analytic review of leader -member exchange theory: Correlates and construct issues. Journal of Applied Psychology, 82(6), 827-844. 
Gourneau, B. (2014). Challenges in the first year of teaching: Lessons learned in an elementary education resident teacher program. Contemporary Issues in Education Research, 7(4), 299-318.

Graen, G., \& Novak, M. A. (1982). The Effects of Leader-Member Exchange and Job Design on Productivity and Satisfaction: Testing a Dual Attachment Model. Organizational Behavior \& Human Performance, 30(1), 109131.

Graen, G. \& Uhl-Bien, M. (1995). Relationship-based approach to leadership: Development of leader-member exchange $(\operatorname{lmx})$ theory of leadership over 25 years: Applying a multi-level multi-domain perspective. American Psychological Association, 6(2), 219-247.

Henry, P. (2011). The role of group-based status in job satisfaction: Workplace respect matters more for the stigmatized. Social Justice Research, 24(3), 231-238.

Hoigaard, R., Giske, R., \& Sundsli, K. (2012). Newly qualified teachers' work engagement and teacher efficacy influences on job satisfaction, burnout, and the intention to quit. European Journal of Teacher Education, 35(3), 347-357.

Huck, S. (2012). Reading statistics and research. (6 ${ }^{\text {th }}$ ed.). Boston, MA: Pearson Education, Inc.

Janssen, O., \& Yperen, N.W. (2004). Employees' goal orientations, the quality of leader-member exchange, and the outcomes of job performance and job satisfaction. The Academy of Management Journal, 47(3), 368-384.

Jones, N., Youngs, P. (2012). Attitudes and affect: Daily emotions and their association with the commitment and burnout of beginning teachers. Teachers College Record, 114(2), 1-36.

Kopkowski, C. (2008). Why they leave? National Education Association. Retrieved from http://www.nea.org/home/12630.htm

Kumcagiz, H., Ersanli, E., Alakus, K. (1999). Hopelessness, procrastination, and burnout

in predicting job satisfaction: A reality among public school teachers.

International Journal of Academic Research, 6(1), 333-339.

Laschinger, H. S., \& Finegan, J. (2005). Using empowerment to build trust and respect in the workplace: A strategy for addressing the nursing shortage. Nursing Economic, 23(1), 6-13.

Lawrence, E. R., \& Michele Kacmar, K. (2012). Leader-member exchange and stress: The mediating role of job involvement and role conflict. Journal of Behavioral \& Applied Management, 14(1), 39-52.

Liden, R. C., Sandy, W.J., \& Stilwell, D. (1993). A longitudinal study on the early development of leader-member exchanges. Journal of Applied Psychology, 78 (4), 662-674.

Loi, R., Chan, K. W., \& Lam, L. W. (2014). Leader-member exchange, organizational identification, and job satisfaction: A social identity perspective. Journal of Occupational \& Organizational Psychology, 87(1), 4261.

Louisianadepartment of education. (2014). Retrieved November 28, 2014, fromhttps://www.louisianabelieves.com/

Louisiana department of education. (2017). Retrieved September 14, 2017,

https://www.louisianabelieves.com/resources/library/enrollment-counts

McMillan, J. H. \& Schumacher, A. (2001). Research in education: A conceptual introduction. ( ${ }^{\text {th }}$ ed.). New York, NY: Addison Wesley Longman, Inc.

Milner, K., Katz, L., Fisher, J., \& Notrica, V. (2007). Gender and the quality of the leader--member exchange: Findings from a South African organization. South African Journal of Psychology, 37(2), 316-329.

Player, D., Youngs, P., Perrone, F., Grogan, E. (2017). How principal leadership and person-job fit are associated with teacher mobility and attrition. Teaching and Teacher Education, 67:330-339.

Scandura, T. A. \& Pellegrini, E.K. (2010). Trust and leader member exchange: A closer look at relational vulnerability. Journal of Leadership \& Organizational Studies, 15 (2), 101-110.

Somech, A. \& Wenderow, M. (2015). The impact of participative and directive leadership on teachers' performance: The structuring, decision domain, and leader-member exchange. Educational Administration Quarterly, 42 (5), 746-772.

Song, H. (2007). Literature review of teacher job satisfaction. Chinese Education \& Society, 40(5), 11-16.

Ssesanga, K. \& Garrett, R. M. (2005). Job satisfaction of university academics:Perspectives from Uganda. Higher Education, 50(1), 33-56.

Spector, P. E. (1985). Measurement of human service staff satisfaction: Development of the job satisfaction survey. American Journal of Community Psychology, 13, 693-713.

Stand for children Louisiana (2012). How Louisiana evaluates teacher effectiveness: implementing act 54 and compass.

Steiner, D. D. (1988). Value Perceptions in Leader-Member Exchange. Journal of Social Psychology, 128(5), 611.

Swarnalatha, C. \& Sureshkrishna, G. (2013). A study on the effects of managerial initiatives on job satisfaction among employees of automotive industries in India. Pakistan Journal of Statistics, 29(5), 659-672. 
Thornton, B., Peltier, G., \& Medina, R. (2007). Reducing the Special Education Teacher Shortage. Clearing House, 80(5), 233-238.

Tsai S-B, Huang C-Y, Wang C-K, Chen Q, Pan J, Wang G, et al. (2016) Using a Mixed Model to Evaluate Job Satisfaction in High-Tech Industries. PLoS ONE 11(5): e0154071. https://doi.org/10.1371/journal.pone.0154071

Volmer, J., Niessen, C., Spurk, D., Linz, A., \& Abele, A. (2011). Reciprocal relationships between leader-member exchange $(\operatorname{lmx})$ and job satisfaction: A cross-lagged analysis. Applied Psychology: An International Review $60(4), 522-545$.

Wolfe, K. (2015). Curriculum reform as adaptive leadership challenge. Change: The Magazine of Higher Education, $47(3), 62-65$. 